\title{
Kadına yüklenen misyonlar bağlamında Aydemir romanı
}

\section{Gaye Belkız YETER ŞAHİN1 \\ Selin Cansu YETER²}

\begin{abstract}
APA: Yeter Şahin, G. B.; Yeter, S. C. (2020). Kadına yüklenen misyonlar bağlamında Aydemir romanı. RumeliDE Dil ve Edebiyat Araştırmaları Dergisi, (Ö7), 298-314. DOI: 10.29000/rumelide.808709.
\end{abstract}

\section{Öz}

Bu çalışmada Müfide Ferit TEK’in Aydemir adlı romanı Milli Mücadele sürecinde kadınların aktif rolü ve fonksiyonu bağlamında incelenecektir. Aydemir adlı roman Milli Mücadele döneminde milli ruhu inşa etmek için çabalayan Demir ve Hazin gibi kahramanların hem Anadolu'daki hem de Anadolu dışındaki zorlu hikâyesini konu edinir. Romanda toplum içindeki sıkıntılara, savaşın yıkıcı sonuçlarına özellikle de milliyetçi düşüncenin yayılmaya başlandığı böylesi bir dönemde kadınların değişen toplumsal ve bireysel rollerine ayna tutulmuştur. Romanın en önemli kadın karakteri olarak karşımıza çıkan Hazin modern bir hayat tarzına sahiptir. Romanda erkeklerin yanında hayatın içinde aktif roller üstlenen Hazin gibi vatansever kadınların pozisyon ve misyonlarına yer verilmiştir. Biz de bu çalışmada Milli Mücadele sürecinde kadınların sosyal hayatında meydana gelen gelişme ve değişim çerçevesinde romandaki kadın karakterin kurgu içindeki ideal fonksiyonuna dikkat çekeceğiz.

Anahtar kelimeler: Müfide Ferit Tek, Aydemir, modernleşme, feminizm, değişen kadın figürü

\section{The novel Aydemir in the context of the missions imposed on women}

\begin{abstract}
In this study, Müfide Ferit TEK's novel named as Aydemir will be examined in the context of the active role and function of women in the process of National Struggle. The novel, Aydemir, focuses on the challenging story of heroes like Demir and Hazin, who struggled to build the national spirit during the National Struggle period, both in Anatolia and abroad. In the novel, the problems in the society, the destructive consequences of the war, and especially the changing social and individual roles of women in such a period when nationalist thinking began to spread are reflected. Hazin, who is the most important female character of the novel, has a modern lifestyle. In the novel, the positions and missions of patriotic women like Hazin who take active roles along with men in life. In this study, we will draw attention to the ideal function of the female character in the fiction within the framework of the development and change in women's social life during the National Struggle.
\end{abstract}

Keywords: Müfide Ferit Tek, Aydemir, modernization, feminism, changing female figure

Dr. Öğr. Üyesi, Erzincan Binali Yıldırım Üniversitesi, Fen Edebiyat Fakültesi, Çeviribilim Bölümü (Erzincan, Türkiye), gayeyeter@hotmail.com, ORCID ID: 0000-0002-4290-9920 [Makale kayıt tarihi: 20.07.2020-kabul tarihi: 20.10.2020; DOI: $10.29000 /$ rumelide.808709]

2 YL Öğrencisi, Ondokuz Mayıs Üniversitesi, Kadın ve Aile Araştırmaları Bölümü (Samsun, Türkiye), slnytro24@gmail.com, ORCID ID: 0ooo-0oo1-9176-4193 


\section{Giriş}

“İnkılâbın nuru bir cemiyete daima kadınların vasıtasıyla akseder.” (Ömer Seyfettin)

Meşrutiyet sürecinde Osmanlı Devleti’ni içinde bulunduğu zor durumdan kurtarmayı amaçlayan Türk aydını İslâmcılık, Osmanlıcılık, Türkçülük ve Batıcılık fikir akımlarıyla dönem sorunlarına çözüm bulmaya çalışırlar. Özellikle 1913’te devlet politikası hâline gelen Türkçülük hareketi edebiyat dünyasını da etkiler (Soğukömeroğulları, 2020). Bu minvalde Halide Edip Adıvar, Müfide Ferit Tek gibi kadın yazarların edebi metinleri; milliyetperverliği, siyasal, sosyal, iktisadi ve eğitim alanlarında var olan problemlerin çözüm yollarını ayrıca Türkiye Türkleri ile Türkiye dışındaki Türkleri konu edinmeleri noktasında önemlidir. Her iki kadın yazar Balkan ve I. Dünya Savaşları sonrasında Türkçü ve Turancı düşüncenin temsilcisi olarak kabul edilirler. Müfide Ferit’in Türkçülük düşüncesi ve feminizm içindeki yerinin anlaşılması bu çalışma açısından önem arz etmektedir: "Daha çok bir düşünce ve eylem kadını olarak öne çıkan Müfide Ferit’in yazı faaliyeti, 1913 yılında Türk Yurdu’nda Süyüm Bike, Sevim Bike müstearıyla yayımlanan 'Hayat Hanım' isimli hikâyesiyle başlar. (...) Ayrıca Aydemir romanını basan Türk Kadını Cemiyeti’nde de faaliyette bulunmuş ve 1919 yllında cemiyetin dershanesinde 'Feminizm' üzerine bir konferans vermiştir” (Demircioğlu, 1998 (a): 14).

Türkçülük düşüncesinin benimsemesi ve yayılması noktalarında aktif bir rolü olan Müfide Ferit’in Aydemir adlı romanı Mehmet Fuat Köprülü'nün ifade ettiği üzere Milli Mücadele'nin henüz başlamadığı zamanlarda milliyetçilik düşüncesini ve Osmanlı coğrafyası içindeki dış Türklerin yaşadığı sıkıntıları anlatan ikinci roman olması hasebiyle önemlidir (Köprülüzade, 2002: 144).

Müfide Ferit Tek’in Aydemir adlı romanını Millî Mücadele içinde hem Anadolu'daki hem de Anadolu dışındaki Türklerin var oluş gayretlerini ve asimile olmama adına yaptıkları mücadeleleri anlatması bağlamında Meşrutiyet dönemi içinde bu konuları işleyen ikinci roman olarak kabul edebiliriz. Anadolu dışındaki Türkler romanımızda ilk defa II. Meşrutiyet döneminde (milliyetçilik eğilimlerinin yoğunlaşmasının da etkisiyle) işlenir (Kaplan, 2002: 163). Bu bağlamda Aydemir romanı, muhtevasıyla yazıldığı dönemin kültür hayatını ve düşünce dünyasını yansıttığı için ayrı bir dikkatle okunmalıdır: "Yayımlandığında edebiyat çevrelerinde büyük yankı uyandıran Aydemir adlı roman, doğrudan doğruya Türkçülük ideolojisi doğrultusunda kaleme alınmış olup Osmanlı Devleti'nin çöküş yıllarındaki ulusçuluk etkinliklerini anlatmaktadır" (Kolcu, 2018: 262).

Öte yandan 1918'de Türk Kadın Mecmuası tarafından yayınlanan Aydemir, Türk Kadın Mecmuası'nda yayımlanan ilk roman olma özelliğine de sahiptir (Demircioğlu, 1998 (b): 9).

Romanın temel tezlerinden birini oluşturan kadının değişen fonksiyonu, yazarın kadınların eğitimine, bireysel, sosyal ve siyasal şartlarının iyileştirilmesine yönelik izlediği programla doğrudan ilişkilidir. Çünkü Müfide Ferit Tek’in "Türk kadınının kabiliyetine güveni sonsuzdu. Cahil kadınları aydın kadınların kalkındıracağına inanırdı" (Üngör, 1972: 40). Yazarın böylesine olumlu fikirleri ve dünya görüşü roman kahramanı Hazin’in dünya görüşüyle kesişir, kinaye mesafesi ortadan kalkar. Romanda yazarın hayatından da izler bulunmaktadır.

"Müfide Ferit Tek Hanımefendi, kişiliği, kültürü, yurt ve insan sevgisi ile çevresinde ve bulunduğu her yerde, seviyeli, onurlu, seçkin ve asil Türk kadınlığını üstünlükle temsil etmiş ve kafes arkasındaki şarklı dişi yaratık masalını hem yazıları ve davranışları ile (...) silmeye çalışmıştır” (Üngör, 1972: 40). 
Müfide Ferit Tek’in eşi tarafından hayatın her alanında desteklenmesinin izdüşümünü Aydemir romanında Demir'in Hazin'e yüklediği rollerde görmekteyiz.

\begin{abstract}
"Müfide Ferit’in siyasi kişiliğinin şekillenmesinde eşi Ahmet Ferit Tek, enişteleri Yusuf Akçura ve Zühdü İnhan, Fransa'daki lise eğitimi esnasında kendisine velilik yapan Ahmed Rıza, Türk Ocağı başkanlarından Hamdullah Suphi Tanrı̈ver gibi isimler etkili olmuşlardır. Ailesi dolayısıyla siyasetin içinde bulunan Müfide Ferit İfham, Hakimiyet-i Milliye, Türk Kadını ve Türk Yurdu gibi yayın organlarında yayımlanan yazılar yazarak ve Türk Kadını ve Türk Ocağı cemiyetlerinde etkili olarak siyasetle aktif olarak da ilgilenmiştir" (Sünbüloğlu, 2012: 510).
\end{abstract}

Tanzimat'tan bugüne kadının toplum içindeki yeri tartışma konusuyken daha çok sosyal hayatın içinde pek yer almayan, meydanlara çıkmayan, göz önünde olmayan, salon kadınlarına yani şehirli kadına romanlarda yer verildiğini söylemek mümkündür (Kurnaz, 2011: 73). Kadınların toplum içindeki yeri kadına tanınan haklarla birleştirilince Meşrutiyet edebî metinlerinde kadın çok daha etkin bir şekilde karşımıza çıkar. Örneğin dönem yazarlarından Müfide Ferit Tek’in Aydemir adlı romanındaki idealist kadın karakteri için Ali İhsan Kolcu'nun yorumu şöyledir:

"Onun sadece yüz ve vücut güzelliğinin bir numunesi ve aşk denilen tutkunun nesnesi olarak değil de bir kafası, ruhu ve fikri olan bir varlık olarak toplumun içinde görev ve sorumluluk üstlenen bir figür olarak ortaya çıkışının örneklerinden biridir” (Kolcu, 2018: 266).

Yaşadığı döneme göre yenilikçi ve ilerici bir görüşle hareket eden Müfide Ferit’in Aydemir romanında kurguladığı roman kahramanları sosyal statüleri açısından hem bireysel hem de toplumsal alanda eskiye nazaran daha fazla değer kazanır.

Romanda İkinci Meşrutiyet yıllarında Türkistan'daki Türkleri bilinçlendirmek, onlarda Türklük ideali ve sevgisi uyandırarak Türk birliğini sağlamak (Pantürkizm) isteyen bir gencin hikâyesi anlatılmaktadır. Türkistan'ın 19. yüzyılın ikinci yarısında Çarlık Rusya tarafından işgalinin ardından verilen mücadelenin anlatıldığı romanda Demir milli benliği koruma şeklinde idealini gerçekleştirmek için Türkistan'a gider. Onun bu ideale kavuşma isteği çocukluk ylllarına dayanmaktadır: "Küçük yaşta anne ve babasını kaybeden Aydemir, Türkçülük idealine çocukluk çağındaki hatıralarıyla ulaşır. Anne ve babasını çok küçükken kaybeden Demir, dedesinin hatıralarını dinlemesi, küçük yaşlardaki kısa Rusya seyahati ve dönemin siyasi, sosyal şartları Aydemir’in Türklük idealine bağlanmasında oldukça etkili olur" (Soğukömeroğulları, 2020). Demir'in Türkistan'da yaptığı büyük fedakarlıkların yanı sıra İstanbul'da özel ders verdiği dönemde tanıştığı Hazin'le yaşadığı aşk ve onun bir kadın karakter olarak değişen misyonun ön plana çıkarılması romanın merkezinde yer alan bir diğer konudur (Tek, 2002: 34). Demir'e hayran olan Hazin bu hayranlığını Demir'in milliyetçi idealiyle birleştirerek kendi hayatına taşır. Hatta Hazin'in Demir'e duyduğu aşk ve arzu milli bir karaktere bürünür. Öyle ki Hazin, Türk ocaklarına üye olur, Türkistan'a gider ve orada Türklerin Ruslar karşısında asimile olmalarını engelleme görevini Demir'den devrahır.

İki bölümden oluşan romanda birinci bölüm Demir'in İstanbul'daki yaşamından ibaretken ikinci bölüm Demir'in Türkistan dönemidir. İstanbul'da ılımlı bir Meşrutiyetçi olan Nedim Paşa'nın kızı Hazin'e âşık olan Demir beşeri aşkı ve öz ülküsü arasında trajik bir hayat sürmektedir. Kızlarının eğitimine çok önem veren Nedim Paşa, Saray'dan özel izin alarak kızlarını Paris'e eğitime gönderir. Hazin konservatuara, Nevin tıp fakültesine kaydolur. Hazin'le tekrar Paris'te karşılaşan Demir onunla görüştükten sonra Türkistan, Azerbaycan ve Mazendaran'a giderek orada milli bilinci uyandırıp tüm Türkleri tek çatı altında birleştirmeyi amaçlar ve Meşrutiyet'in ilanından sonra İstanbul'a döner. Hazin ve Nevin ise Saray'm baskısıyla çoktan İstanbul'a dönmüşlerdir. Hazin Almanya'da tahsilinden yeni dönen genç zabit Neyir ile evlendirilmiştir: "Nedim Paşa'nın, Saray'dan uzaklaştırılmasıyla beraber 
çıkan ikinci bir irade onları geriye çağırdı. Geldiklerinin altıncı ayı Hazin, yine padişahın yeni bir iradesiyle, istemediği, sevmediği, Neyyir ile evlendiriliyor" (Tek, 2002: 23). Bu cümlelerden de anlaşllacağı üzere Hazin’in kendi isteği dışında evlendiği görülmektedir. Romanda -zorla- evlilik hadisesi ise şöyle anlatılmaktadır: Neyyir, "Nedim Paşa'dan kızını istetti: fakat o vermedi. O zaman intihara kalkıştı. Neyyir'in babası Adliye Nazırı idi. İş padişaha kadar aksetti; padişah acıyarak hususi bir iradeyle Hazin'in Neyyir'le nikâhını kıydırdı" (Tek, 2002: 26). Nedim Paşa, Padişah'ın emrine karşı gelemeyince bu evlilik gerçekleşmiş olur. Bir kadın olarak ayıplanacağını düşünerek her zaman aşkla ilgili duygularını gizlemek zorunda kalan Hazin bu acziyetiyle sevmediği bir adamla evlendirilir: "Sonra bir gün aralarına Neyyir girdi. Hazin'in ne engellemeleri, ne isyanları, ne gözyaşları hiç, hiçbir şey fayda etmemişti. Ve bütün o sevgili ümitleri, aşk rüyaları, istikbal hayalleri hep müstebit bir emrin buzlu nefesi önünde cereyanlarını keserek döndüler. Hazin, çılgınlı̆̆ın yeisleriyle inledi. Herkese darıldı. Neyyir'e, padişaha, kendisini müdafaa edemeyen babasına!... bir zaman geldi ki hayatını ve kalbini kıran bu elemi artık saklayamaz oldu ve kimseyi görmeden aylar geçirdi” (Tek, 2002: 53). Paris'te doktora yapan Hazin'in evlilik hususunda kendi kanaatini belirtemeyişi ve kızlarının eğitimine bu kadar önem veren babasının görücü usûlü evlilikle ilgili kızını ikna edişi oldukça düşündürücüdür. Öyleyse romandaki bu hadiseyi o dönem kadınlarının büyük bir çoğunluğunun ebeveyn baskısıyla hâlâ bazı alanlarda kendi arzularını ve isteklerini gerçekleştiremedikleri şeklinde yorumlayabiliriz. Genç kadının mutsuzluğu devam ederken Demir bir seyahate çıar ve Hazin de -hiçbir zaman başaramayacağı bir duyguya kapılarak- Demir’i unutmaya karar verir. Bir akşam köşkün bahçesinde Hazin'le buluşan Demir ona Türkistan'a seyahatinden ve orada gerçekleştirmek istediği planlardan bahseder. Hatta Hazin'e bu hususta milli mesaide İstanbul'daki yardımcisı olması teklifinde bulunur. Çünkü Demir'e göre Türk birliği fikri, İstanbul ve Anadolu'da başlayacak ve Türkistan da yayllacaktır: "Aydemir yaşamını Rus yönetimince baskı altına alınan ve sömürülen Türkler arasında milliyetçilik duygularını yaymaya adamış olan genç bir adamdır” (Zengin, 2017: 563).

Hazin bir gün Demir'e âşık olduğunu itiraf eder ve genç adamın da benzer duygular içerisinde olduğunu anlar; lâkin Demir milli öz ülküsünü maddi duygularından daha ön planda tutar ve Hazin'e uzun bir mektup yazarak Türkistan'a gider. Aşk acısına rağmen Türkistan'da çok mutlu olan Demir halk tarafından da çok sevilir. Hatta köylülere yardım etmesi, cehaleti önlemeye çalışması, işsizlere iş bulması, okuma-yazma öğretmesi ve milli mücadelenin kazanılacağı günü müjdeleyerek halkı ayakta tutması nedeniyle halk onu "mehdi” olarak görmeye başlar. Türkistan'da halkın sevgilisi olan Demir'in Hazin'e duyduğu özlem her geçen gün artmakta iken Trablusgarp Savaşı'nda hastalanarak İstanbul'da ölen Neyir'in haberinin verildiği mektup onda Hazin'e kavuşabileceği düşüncesini doğurur: "Hazin serbest! Hazin benim olabilecek!..” (Tek, 2002: 73). Bu haber Demir'de Hazin'e kavuşup onunla evlenebilme düşüncesini oluştursa da Milli dava için verdiği mücadeleyi yarıda bırakıp İstanbul'a dönme cesaretini gösteremez. Semerkand'a giderek Ahund Ömer'in medresesini ıslah etmeye çalışır. Orada sadece bununla kalmaz gazete çıkarır; Ziraat Bankası'nı açar; işçi sendikası kurar; mektep açar. Açtığı mekteplerde yetişen her bir idealist öğrenci ise onu Aydemir olarak adlandırmaktadır. Bu gelişmelerden rahatsız olan Ahund Ömer ise Demir'in aleyhinde propaganda yapar. Bu olumsuz gelişmelerin yaşandığı zaman diliminde Demir hastalanır. Ulu Mirza'nın medresesinde "kapısı daima kilitsiz duran, soğuk odasında" hastalanan Demir bu hastalıktan kurtulamayacağının farkına varır (Tek, 2002: 93). Öleceğini düşünen Demir Hazin'e bir mektup yazarak yarım kalan büyük işini tamamlaması için onu Türkistan’a çağırır.

I. Dünya Savaşı ortaya çıtığı günlerde Demir isyan etmek isteyen halkı bu fikirlerinden caydırır. Ancak Ahund Ömer isyana teşvik suçundan yargılanıp idam edilecektir. Ahund Ömer'in karısı Demir'e gelip bir çare bulması için yalvarır. Zaten hastalık nedeniyle öleceğini bilen Demir, Ahund'u kurtarmak 
için suçu üstlenir; Lakin Demir'in planlamadığı bir şey olur ve yanındaki on iki öğrencisi de idama mahkûm edilir (Tek, 2002: 102). Genç adam, Ahund Ömer’i kurtarmak isterken kendi öğrencilerinin de suçlu konuma düşeceklerini hiç hesaplayamaz. Öğrencilerinin teker teker idam edildiğini gören Aydemir, karşısında ona secde eden Ahud Ömer’i de görünce şaşırır ve hiç tereddüt etmeden başını ilmiğe geçirir. 'Sevdiği 'Hazin’ini ve milletini düşünerek 'Yaşasın Türkler!' diye bağırdıktan sonra başını ilmiğe geçirir” (Tek, 2002: 123). Hazin İstanbul'dan Semerkant'a gelir; lâkin Demir’i sağ bulamaz. Mezarını ziyaret eder, Demir'e olan beşeri aşkı milli aşka dönüşür ve bu aşkı yaşatacağına yemin eder.

Romanda ideal erkek konumundaki Demir’in davasına adanmış bir hayattır Hazin'inki. Çünkü Hazin güçlü bir kadın olarak her daim sevdiği adama cephe gerisinden destek verecektir. Örneğin genç kadının kızlar için okul kurması, aşkını vatan uğruna feda ettiği örneklerden sadece biridir. "İstanbul'dan gelip sevgilisinin mezarını ziyaret eden Hazin, ona olan aşkını milli aşkın içinde yaşatacağına yemin ediyor ve bu suretle, kendi hayatının ve aşkının ıstıraplarının üstünde, aşk ve umut dolu ebedi bir hayata, ilâhî mefkûreye kavuşuyor" (Köprülüzade, 2002: 149). O her zaman Demir’i destekleyen, onun iradesini zayıflatmamak için aşkını ikinci planda bırakan, vatansever bir kadın olarak kurgulanmıştır. Roman da bu kurguya hizmet eder şekilde şöyle sonlandırılır:

"Kalbi dolu fakat beyni serinlemiş, eğildi mezarı bir daha öptü.

-Senin sevgili ve mukaddes mezarın üstüne yemin ederim ki Demir, seni öldürmekle fikrini, emelini, mevcudiyetini öldüremezler... Senin vazifeni, senin emelini, kendime mübarek bir vazife edinerek senin yerine çalışacağım...” (Tek, 2002: 129).

Anlatının sonunda Demir’in mezarı başında sevdiği adamı kaybeden üzgün hem de onun hayalini gerçekleştirecek güce, donamına sahip kuvvetli ve bir o kadar da bilinçli, kahraman bir Türk kadınına dönüşen Hazin’i görmekteyiz.

Romanın olay örgüsünde yer alan aşk ilişkisi doğrudan milliyetçi söylemi inşa etmek ve toplumsal, kamusal alanda kadın kimliğinde yaşanan değişimi göstermek içindir. Öte yandan Demir'e kavuşamayan Hazin'in teselli için Demir’in Türk birliği idealine sahip çıkmayı yeğlediği söylenebilir. Olay örgüsünde vatan meseleleriyle alâkalı kadın kahramanın fikirlerini açıkça ifade edebilecek bir ortama ve bilgiye sahip olması -kendi başına eyleme geçmese de- yeni kadın modelinin de eserdeki yansımasına örnek teşkil etmektedir. Dramatik aksiyon unsurlarından aşkın romandaki işlevi ise yeni kimlik inşasında bireylere nasıl yardımcı olduğunu göstermek içindir. Özellikle de Demir’in ideallerinin yer aldığı aşk mektuplarını okuyan Hazin'in siyasi ve toplumsal meselelerde bilinçlendiğini söyleyebiliriz.

\section{A. Müfide Ferit'in perspektifinden kadın figürü}

Tanzimat'la birlikte başlayan toplum içindeki değişim ve çalkantı milli kimliği inşa sürecinde çoğunlukla birer sorun ya da ikilem olarak karşımıza çıkmaktadır. Özellikle de Batılılaşma sürecinin hız kazanmasıyla kadının değişimi devletin bekasıyla da ilişkili bir hâl alır. Tüm bu değişimler dönem romanlarında çeşitli yönleriyle işlenir. Kadın yazarlar eserlerinde bu hususta yol gösterici olmuşlar ve yer yer ideal kadının nasıl olması gerektiğini ifade etmişlerdir. Hatta kadınların feminist çıkışları ve siyasi alanda varlık göstermeleri Milli Mücadele’yi konu alan romanların pek çoğunda önceki dönem romanlarına kıyasla daha çok işlenir. Özellikle de Müfide Ferit gibi feminist milliyetçi görüşlere sahip yazarların eserlerinde kadınların hak ve özgürlüklerine yönelik söylemlere sıkça rastlamak mümkündür: 


\begin{abstract}
"Balkan ve Trablusgarp savaşları ile bu savaşların kadının hayatında oluşturduğu değişiklikler onun sosyal hayata karıșmasını zorunlu hale getirir. Kadınların savaș ortamının doğurduğu zorunluluklar sonucunda iş hayatına girmesi, toplumsal yaşamda da rolünü değiştirmiş, toplumda kadının görünürlüğü artmıştır. Osmanlı toplumunda yaşam rolü değişen kadının kültürel ve edebî hayata yansımaları da gecikmez. Feminist milliyetçi hareketin Halide Edip'ten sonra en ünlü ve en etkin isimlerinden birisi de Müfide Ferit'tir" (Şermet, 2019: 141-142).
\end{abstract}

Sevim Karabela Şermet'in de ifade ettiği gibi Müfide Ferit Tek edebiyatçı olmasının yanı sıra bir düşünce ve eylem kadını misyonunu üstlenir. Bu sebeple onun eserlerindeki kadın karakterlerin metne nasıl ve hangi görünümlerde yansıdığı hususuna yer verilmeden önce yazarın kadınlara yönelik faaliyetlerinden bahsetmek faydalı olacaktır. Öncelikle Müfide Ferit Tek Meşrutiyet yanlısı bir subay olan eşi Ahmet Ferit Bey'den pek çok hususta etkilenir. Ayrıca siyasi hayatında kocasını destekleyerek kendini de yetiştirmiş ve geliştirir (Mansuroğlu, 1972: 42). Müfide Ferit’in siyasi ve sosyal hayat içerisindeki aktif yönünün gelişmesinde kocası Ahmet Ferit Tek'in yanı sıra aile eşrafı ve arkadaş çevresinin de büyük desteği vardır:

"Genç kalemlerin yaygın ve güçlü etkileri elbette bu seçkin kadınlarımıza da tesir edecekti. Müfide Ferit Hanım, özellikle eniştesi olan Türkistan Türklerinden Yusuf Akçura'nın da büyük ölçüde telkinlerine ve Gökalp’in merhale merhale gelişen Türkçülük akımına uyarak o da eski ve soylu bir ulustan geldiğine inanıyor, yıkılmakta olan İmparatorluktan kurtarılacak değerleri, yeni nesillere aktarmaya çalışıyordu" (Mansuroğlu, 1972: 42-43).

Aydemir adlı romanda Müfide Ferit ve eniştesi Yusuf Akçura'nın hayatından izlere rastlamak mümkündür (Şermet, 2019: 140). Romanın kahramanı Aydemir’in Yusuf Akçura ile özdeşleştirilmesi yazarın tüm Türkleri tarih ve kültür ortaklığında bir bayrak etrafında birleştirme arzusuyla bağlantılıdır. Öte yandan milliyetçilik fikri, siyasi alt zeminde değil de daha çok kültürel anlamda hayat buldurmaya yöneliktir (Demircioğlu, 1998 (a): 16).

Hayat hikâyesinden de anlaşılacağı üzere aile ve arkadaş çevresi tarafından sürekli desteklendiği görülen Müfide Ferit, Millî Mücadele'nin kazanılmasında kadınların büyük payının olduğunu düşünür: “Müfide Ferit Hanım'ın şahsiyetini meydana getiren bilgi, içtenlik, ulusuna inanç yanında kadınlığının zarafeti sanırım en güçlü tarafıdır. Bu silâhla bütün kapalı kapılar tılsımlı bir dokunuşla açılıyor ve karşısındakini derhal etkisi altına alıyordu" (Mansuroğlu, 1972: 43). Öte yandan Müfide Ferit eserlerinde kadın haklarını esas alan pek çok konuya yer verir:

\begin{abstract}
“Müfide Ferit'e özgü feminizm ötekileștiren ve iki cinsi birbirine yabancılaștıran değil temelinde insani ögeler barındıran bir anlayışı gizler. Müfide Ferit’in kadına bakışı ve şahsına özgü feminizmin şifreleri konferans/anket/mülakat metinlerinde gizlidir. Dönemin aydın kadınlarından biri olarak feminizmi alışılmış, sıklıkla kullanılan türler dışında modern, henüz devrin aydınlarının dahi yeni alışmaya çalıştıkları türlerde ifadesi de göz ardı edilmemesi gereken bir tutumdur" (Şermet, 2019: 149).
\end{abstract}

Görüldüğü üzere kadın hakları hususunda çalışmaları bulunan Müfide Ferit’i tam anlamıyla feminizmin savunucusu olarak kabul edemeyiz. O daha çok bir kadınının kültürel ve toplumsal normlarla örtüşen yaşam şekline dikkat çekmektedir. Feminizm hususunda ılımlı bir tavır içinde olduğunu söyleyebileceğimiz Müfide Ferit’in Aydemir adlı romanını yazarın kadın meselesiyle ilgili düşünceleri ışı̆̆ında yorumlamaya çalışacağız.

Yazar hem Avrupa'da hem de Türkiye'de feminizm konulu konferanslar verir. Onun bu konferanslarındaki konuşmaları hem çağında hem de sonraki süreçlerde kadın meselesi hususunda önemlidir: "Osmanlı Devleti’nde feminizm konusunda özellikle yazılarıyla önemli girişimlerde bulunmuş kadınlarımızdan birisi de Müfide Ferit’tir” (Avcı, 2016: 243). Özellikle kızların eğitimine çok 
önem veren Müfide Ferit Tek bu şekilde kadınların hem aile içinde hem de hayatın her alanında başarılı olabilecekleri görüşündedir: "Kızların eğitimi çok önemlidir. Kadınların bir yandan sıcak, temiz, medeni, ahlâki bir aile ocağı oluşturmaları, diğer yandan çalışma hayatında erkeklerle eşit şartlarda birlikte yürüyebilmeleri gerektiğini söylemiştir" (Avcı, 2016: 244). Toplumsal düzlemde daha çok eğitim ve çalışma hayatında eşitlik isteyen Müfide Ferit Tek, bu şekilde kadınların toplum içinde önemlerinin artacağı inancındadır. Örneğin Aydemir romanında Hazin karakteri bağlamında Türk kadınının Milli Mücadele sürecinde erkeklerle birlikte bu harekete nasıl dahil oldukları anlatılmaktadır.

Müfide Ferit Tek çeşitli ulusal ve uluslararası platformlarda Türk kadınına duyduğu güveni hem yazılı hem sözlü olarak ifade etmekten geri durmaz:

\begin{abstract}
"Müfide Ferit bulunduğu ülkelerde Türk kadınını başarı ile temsil ederek Türk kültürüne katkılarda bulunmuştur. Eşi Ahmet Ferit Tek'in büyükelçilik görevi dolayısıyla dünyanın farklı bölgelerinde yaşaması ve bu bölgelerde Türk kadını imajını zedelemeden sergilediği duruşu, Almanya'da yayınlattığı romanı, Pierre Loti ile görüşmeleri, Fransız aydın ve yazarları ile diyalogları, toplumsal huzura katkı oluşturacak Soroptimist faaliyetlerin başında yer alması Türk kadınının yurt dışında temsili açısından önemlidir” (Şermet, 2019: 146).
\end{abstract}

Müfide Ferit Tek ulusal ya da Milli Edebiyat dönemi olarak adlandırılan 1911-1923 yılları arasında romanlarını daha çok milliyetçilik duyguları çerçevesinde kaleme almıştır. "Müfide Ferit'in Yusuf Akçura'nın da teşvikiyle ve birinci harpten mağdur çıkan millete teselli olsun diye yazdığı Aydemir, Sinop’taki sürgün yıllarının eseridir” (Demircioğlu, 1998 (a): 16). Ayrıca Turancılık düşüncesi için özel bir önem atfedilen Aydemir romanında ileri sürülen kültürel pantürkizm ve Türklerin birliği düşüncesi, Misak-ı Milli sınırlarıyla tanımlanan yeni bir milliyetçiliğe zemin hazırlar (Demircioğlu, 1998 (a): 14).

Millî Mücadele sürecinde kadınlar da erkeklerle aynı koşullarda mücadeleye başlamışlardır. Bazen hemşire, asker, öğretmen gibi görevlerle Vatan Yahut Silistre'nin erkek kıllı̆ına girerek cepheye giden kadın kahramanı Zekiye'den farklı olarak erkek kılı̆̆ına girmeden evlerde, sokaklarda, meydanlarda, cephelerde kadın kimlikleriyle yerlerini almaya başlamışlardır. Sevim Karabela Şermet, Müfide Ferit’in kadınların rollerine ilişkin görüşlerini şöyle ifade eder:

"Müfide Ferit kadının sosyalleşmesi ve iş hayatına girmesi gerekliliğini savunurken kadının ev içi rolünü göz ardı etmez. Aile birlikteliğinin sürdürülmesi gerekliliğine inanan Müfide Ferit'e göre feminizm erkeklerden önde değil birlikte yürümek anlamı taşır ve bu birlikte yürüme isteği son derece insani gerekçelerledir. Bu sebeplerle kadının çalışması meselesine temas eden Müfide Ferit kadın ile erkeğin birlikte ve birbirine eşit koşullarda çalışmasını dikenli bir mesele olarak görür” (Şermet, 2019: 151).

Müfide Ferit'in bu görüşlerinden hareketle Aydemir adlı romanın idealist kahramanı Demir'in de yer aldığı bir konuşma ortamında kadınların ev içindeki rollerine olay örgüsünde şöyle yer verilmektedir: "Hazin çay yapıyor, Nevin de dağıtıyordu. Şekerlemeleri, çörekleri de Hazin aldı" (Tek, 2002: 28). Meşrutiyet yllarında bir kadın yazar tarafından "kadın meselesine" kafa yorulan romanda kadının toplumdaki yeri, giyimi, eğitimi, fonksiyonu, annelik figürü gibi konular işlenir.

Müfide Ferit’in yazılarından da anlaşılacağı üzere yazar kadınların siyasi hayatta yer almalarına karşı değildir. Lâkin bunun henüz erken olduğunu düşünmekte ve kadınların daha çok erkeklerin yanında yer almalarını istediği görülmektedir: "Erkeklerimizin bile bu husustaki iktidarları şüpheli iken bir de kadınları meseleye karıştırmak zamanı henüz gelmemiştir" (Tek, 1335/1907: 325). Bu bağlamda yazarın hatıralarının romana ışık tuttuğunu söylemek mümkündür. Özellikle de Hazin’in Demir ölene 
kadar onun arka planında kalması niyet boyutu kurmacayla doğrudan ilişkilidir: "Kadının erkekleşmesine en sert tepkiye Müfide Ferit Tek’in romanında rastlarız” (Yllmaz, 2016: 48).

Kadınların feminen özelliklerini kaybetmemeleri gerektiğine dikkat çeken yazarın her alanda kadınları desteklediği de görülmektedir. Özellikle de Aydemir adlı romanındaki olaylar Hazin ve Nevin’in ev içi ve ev dışı görev bilinçleri dikkate alındığında yazarın kadınların maskülenleşmesine karşı olduğu düşüncesini zihinlerde uyandırmaktadır:

"Müfide Ferit'e göre, erkekleșen kadın, kadınlığını inkâr eder, ancak yaratılıșı sebebiyle erkek de olamaz. Yazar, feminizmin bu yönüne dikkat çeker. Kadınlı̆̆ını inkâr eden bu kızlar, ne kadın ne de erkek olabilirler. Arada kalan, kimliksiz nesillerin yetişmesine neden olan bu akımın zararları üzerinde duran yazar, feminizme şiddetle karşı çıar” (Yılmaz, 2016: 48).

Öte yandan "Müfide Ferit feminizmin ortaya koyduğu eşitlik düşüncesine tamamen karşı çıkar. Bu düşüncenin menşeinin feminizm olması bile yazar için karşı konulması gereken bir fikir olarak kabul edilir. Bu yazarlar romanlarında erkekleşen kadını kendi değerlerinden ödün veren, fikrî buhrana düşmüş kadın olarak gösterirler" (Yılmaz, 2016: 50).

Zaten yazarın hayatındaki roller ve modeller romanda Hazin’inkiyle benzerlik göstermektedir. Şöyle $\mathrm{ki}$

\begin{abstract}
"Etrafımız korku ve elem içinde idi, fakat evimiz bir aydın saadet ve ileri fikirler yuvası idi. Çok mesut bir çocukluğum oldu. Doğduğum zaman Recep Paşa babama 'Şevketim ismini Müfide koyalım da memlekete Müfid olsun' demiş. Hayatımın vazifesi o gün verilmişti. 3 yaşından itibaren beni okutmaya başlamışlar. O zaman Trablus'ta Türk mektebi olmadığı için 7 yaşımda beni St. Joseph rahibe mektebine verdiler, Fransızca ve İtalyanca öğretiyorlardı. Üç sene sonra babam hastalandı, iyi olamayacağını anlayınca beni acele okutmak istedi, benim doktor olmamı ve o zaman erkek doktora kendini göstermeyen Türk köylü kadınlarına bakmamı istiyordu. Beni gizlice Versailles lisesine gönderdi. Gizli diyorum çünkü o zaman Avrupa'ya gitmek memnu idi. Tahsile dışarıya gönderilen ilk Türk kızı ben oldum” (Tek, 1972: 11).
\end{abstract}

Kızının tıp eğitimi alarak Anadolu'daki kadınlara bakmasını isteyen Şevket Bey, Müslüman kadınların Avrupa'ya gitmesinin yasak olduğunu bile bile kızı Müfide'yi Paris'e eğitim alması için gönderir: "Lise öğrenimini de o devirde hiçbir Türk kadınına nasip olmayan bir düzey ve yerde Paris'te Versailles Lisesi'nde yaptı" (Mansuroğlu, 1972: 42). Müfide Ferit'in kendi hayatını anlatımından da yola çıkarak kendisinin Avrupa'da tahsile giden ilk Türk kızı olması ve ailesinin onu bu hususta desteklemesi Aydemir'de Hazin ve Nevin karakterlerinin eğitim serüvenlerinde tematik bir benzerlik olarak karşımıza çıkar.

Tıpkı Müfide Ferit Tek'in babası gibi roman kahramanı Nedim Paşa, kızları Nevin ve Hazin’in eğitimiyle -dönem şartlarına göre- oldukça fazla ilgilenmektedir: "Onlara memlekette henüz benzeri görülmemiş bir tahsil vermek, onları da memleket için çalıştırmak, Hazin’e tıp tahsili ettirmek ister. Fakat Hazin'in sanatkâr tabiatı bu arzusuna engel olur. Hazin Konservatuara, yapısı tıp tahsiline uygun Nevin ise tıbbiye sınavlarına hazırlanır" (Demircioğlu, 1998 (b): 3-4). Özellikle de Nevin karakteri Paris'teki doktora eğitiminin yanı sıra okumayı seven, bu hususta kendini yetiştirmeyi amaçlayan bir kadın olarak metinde karşımıza çıkar: "Nevin elinde bir ilim mecmuası büyük bir koltuğa gömülmüş oturuyordu. (...) Bu hafta Paris'e gidiyorum. Doktoramı geçmek için! Çok iyi, aferin Nevin Hanım" (Tek, 2008: 37).

Kadınlar açısından romanda dikkat çeken bir başka husus ise kadınların meslek hayatına karışmalarını sağlamaktır: 


\begin{abstract}
"Müfide Ferit, Türk feminizmin önemli isimlerindendir. Gerçekleştirdiği konferanslarda Türk insanını anlatırken dönemin koşulları ile de bağlantılı olarak Türk kadınını merkeze alır. Millî Mücadele döneminde Türk insanının verdiği millî uğraş Türk kadını üzerinden tanımlanır. Müfide Ferit, savaş koşulları altında yalnızlaşan kadınların sorunları üzerinden kadın hakları savunuculuğu yapar. Savaş yıllarında, yaşamak için ekonomiye katkı sağlamak zorunluluğu oluşması sebebi ile toplumsal alanın ortasında kendini bulan kadını ve kadınlığı yazın yaşamına taşır” (Şermet, 2019: 143).
\end{abstract}

Özellikle Türk modernleşmesinin temellerinin atıldığı Tanzimat süreciyle başlayan ve her geçen gün gelişen kadının bireyleşim sürecinin anlatıldı̆̆ı romanda yazarın bu hususla ilgili görüşleriyle hikâyenin paralellik gösterdiğini ileri sürmek mümkündür. Müfide Ferit de sosyal, siyasal sahada değişen Türk kadınının farkındadır ve kadınların toplum içindeki konumları konusuna çalışmalarında sıklıkla yer vermiştir: "Müfide Ferit, Paris yıllarında Fransız kamuoyuna Türk Milli hareketini, Türk kadınını tanıtan konferanslar verir” (Demircioğlu, 1998 (b): 14). Ayrıca kadının konumu konusu büyük oranda kadın cemiyetlerinde yazar tarafından verilen konferanslarla da ön plana çıkarılır.

Aydemir'de tıpkı Felâtûn Bey ve Rakım Efendi, İntibah gibi Tanzimat romanlarına benzer şekilde kadınların çeşitli müzik aletleri çalma hususundaki yönelimlerine dikkat çekilmektedir. Hem batılılaşma kavramı hem de kadınların sanat eğiliminin geliştirilmesi şeklinde değerlendirilebilecek bu faaliyetlere Aydemir'de Hazin'in keman Nevin'in ise Piyano çalması örnek olarak verilebilir (Tek, 2002: 20, 21).

Modernleşmenin ardından toplumsal normların değişimine paralel olarak değişen kadın kimliğini Aydemir romanı üzerinden okumak mümkündür. Müfide Ferit Tek’i ne tam anlamıla feminizmin savunucusu ne de feminizmin dışında kalan bir aydın olarak kabul edebiliriz. O, daha çok kadınların toplum içindeki mevkilerinin yükselmesini arzulamış ve bu amaç doğrultusunda Türk Soroptimist derneğini kurmuş̧ur.

\title{
B. İstanbul'dan Paris'e
}

Romanda Hazin ve kardeşi Nevin'in hemen her alanda Paşa babalarının da desteğiyle çok iyi yetiştirilmeye çalışıldıkları görülmektedir. Tanzimat romanlarında da önemli bir tema olarak karşımıza çıkan kadınların sosyal düzen içindeki konumlarının iyileştirilmesi meselesi Meşrutiyet romanlarında da İstanbul'un dışına çıkarak tüm Osmanlı tebasını kapsar nitelikte geniş bir sahaya yayılır. Meşrutiyet sürecinde sanat ve edebiyat alanında yapılan çalışmalar dikkate alınırsa dönem aydınlarının kadınlara olan inancının ve güveninin bir önceki nesile göre arttı̆̆ını söylemek mümkündür. Söz gelişi Ömer Seyfettin milliyet cereyanın en büyük kahramanlarının kadınlar olduğu yönünde bir görüşe sahiptir (Seyfettin, 2002: 152). Ömer Seyfettin gibi Müfide Ferit de kadınların eğitim alanında kendilerini yetiştirmelerine, hemen her sahada varlık göstermelerine ve cinsiyetlerinin sınırlarını aşmaları gerekliliğine inanır. Bu sebeple Aydemir'de Nedim Paşa kızları Hazin ve Nevin’in eğitimine çok önem verir. Bu şekilde yazar yeniliğe açık kadınların hemen her sahada başarılı olabileceğine yönelik inancını Hazin’in şahsında dikkatlere sunar:

"Onların tahsil ve terbiyesi ile hiçbir babanın uğraşamayacağı gibi uğraştı. Onlara memlekette henüz misli görülmemiş bir tahsil vermek, onları da memleket için çalıştırmak istedi. Hazin’e tıp tahsil ettirmek istiyordu. Hazin'in gayet hassas ve sanatkâr tabiatı, bu arzusuna mani oldu. O, musikiye karşı büyük bir temayül görüyordu. Pederi de razı oldu. Zaten her sanat, her tahsil her kemal memlekette bir hizmet değil miydi? (...) Nedim Paşa, bin müşkülatla aldığı hususi bir irade ile kızlarını Paris'e gönderdi; Fakat bu tahsilleri çok sürmedi” (Tek, 2002: 23). 
Hazin hem İstanbul'da hem de Avrupa'da bulunduğu süre zarfında kendini pek çok alanda yetiştirir. Hazin Paris'e gitmeden önce ve Paris'ten döndükten sonra çeşitli toplantılara katılarak siyasi, sosyal konulara arkadaşlarıyla birlikte çözümler arayan idealleştirilmiş bir kadın karakter olarak karşımıza çıkar. Demir de bu sebeple milli davasına yoldaş olarak Hazin’i seçer. Çünkü ona göre Hazin aydınlık gelecek için desteklenmesi gereken güçlü ve zeki bir kadındır. İşte bu gücü kanıtlamak için yola çıan Hazin’in bireyleşim sürecinde ilk eşik İstanbul, ikinci eşik Paris, üçüncü eşik Türkistan, dördüncü eşik ise cephe gerisidir.

\section{Paris'ten cepheye}

Çalışmanın konusunu oluşturan Aydemir adlı romandaki kadınların sosyal hayatta değişen fonksiyonları dönemin şartlarında iyi bir eğitim alma imkânına sahip Hazin ve Nevin şahıslarında anlatılmaya çalışılmıştır. Topluma faydalı olan milliyetçi kadın prototipinin çizildiği Aydemir adlı romanda yazarın kadınların toplum içindeki etkin rollerini onlara aşılaması metnin önemini artırır. Romanda yeni bir kadın karakter olarak karşımıza çıkan Hazin ve Nevin'in fonksiyonu okuyucunun dikkatini hemen çekmektedir. Bu bölümde Nevin'den ziyade romanda idealist kadının simgesi Hazin’in kendinden önceki dönem kadın karakterlerinden ayrılan yönleri ortaya konulmaya çalışılacaktır.

İstanbul'da yaşayan, paşa kızı Hazin Turancı-Türkçü düşünceye gönül vermiştir: "Türk edebiyatının ilk 'Turancı' romanını, Müfide Hanım'dan on yaş büyük olan Halide Edip, 1912'de yayımlamıştı: Yeni Turan. Aydemir ikincidir" (Belge, 2003: 90). Türkçülük idealinin romandaki simgesi ve temsilcisi Demir'in Hazin ile olan aşkları hep bu ülkü doğrultusunda romanda yer almaktadır. Demir'in ulvi bir vazife olarak gördüğü Turan fikrine karşılık aşkını ikinci planda bırakması ve ardından yaşananlar romanda onun yaptığı bu tercihin sorgulanmasıyla devam etmektedir. Hem Hazin'in hem de Demir'in yaşadığı duygusal çatışma unsuru romanın dramatik aksiyonunu sağlayan unsurların başında gelmektedir. Demir'in Hazin’i İstanbul'da birakarak Rus zulmü altındaki Türkistan'a gitmesi ve oradaki Türk kardeşlerini kurtarma gayreti Demir’in sevdiği kadını bırakıp başka diyarlarda hasret içinde yaşamasına neden olur. Demir tıpkı bir rehber, öğretmen, hatta bir kahraman gibi Türkistan'daki fakir halkın perişan hâlini gözlemlemiş, hastalara yardımcı olup onları tedavi etmiş, gençleri Turan fikriyle bilinçlendirip birlik ve beraberliği sağlamaya çalışarak kurtuluşu hedefler:

“Aydemir karakteri, tavrıyla, fikirleriyle ve hareketleriyle bölgede bir 'peygamber' edası ile tanınmıs,, şaşkın ve korku içindeki Türkistan halkını uyanışa geçirmeye gayret etmiştir. Kendisine kötülük edenlere iyilikle karşılık vermiş (Buda'nın yaklaşımına da sıklıkla yer verilir), bir çocuğun gözyaşına mani olmak için kendinden vazgeçmiş ve Ruslar tarafindan idam edilmiştir” (Akman).

İstanbul dışındaki Anadolu şehirlerinde halkın yoksulluğu, fakirliği, çektiğgi sıkıntılar ve cahilliği gibi mevzulara romanda yer verilmektedir. Çünkü romanda Demir, Doktor Emin, Refik Bey gibi bazı Osmanlı aydınları Anadolu’ya giderek bu problemlere çare bulmaya çalışırlar.

Yazarın ilk romanı olan Aydemir'de, milliyetçilik duygusu ve Türk ideali hikâyenin temelini oluşturmaktadır: "Aydemir adlı roman yayınlandığı dönemde hatırı sayılır bir kitleyi etkilemiş hatta yıllar sonra Şevket Süreyya Aydemir'e soyadı seçiminde ilham kaynağı olmuştur” (Akman). Öte yandan Şevket Süreyya'nın sadece soyadı seçiminde değil aynı zamanda Aydemir karakteri gibi olmak isteği romandan ve roman karakterinden ne derece etkilendiğini ortaya koymaktadır:

“Sarıkamış alınırken bacağı kırılan Şevket Süreyya tedavi gördüğü hastanede Müfide Ferit’in, söz konusu romanında anlattıklarını gerçekleştirmeyi düşler: Ben bir Aydemir olacaktım! (...) Aydemir, 
yarı peygamber, yarı idealist, yarı meczup bir tipti. Fakat bu kitap öyle bir zamanda yazılmıştı ve ben onu, öyle bir yerde, öyle şartlar içinde okumuştum ki, o bana derhal Hakk'ın ilhamı gibi göründü” (Ertop, 2004: 42).

Şevket Süreyya'nın böylesi bir etkilenmesinden yola çlkarsak Ali İhsan Kolcu'nun da ifade ettiği gibi romanda idealize edilen Aydemir ve Hazin karakterleri daha sonra kimi tarihi roman yazarlarınca da taklit edilir (Kolcu, 2018: 263).

Romanın başkahramanı Demir'e göre Anadolu insanının yoksulluğu ekonomik gelişmişlikle ilgilidir ve bu sorunda devletin de büyük payı vardır. Onun bu görüşlerini Hazin ile konuşması ve tartışması kadınların karar mekanizmalarında görünür kılınmaya, söz sahibi olmaya başladıklarını örneklendirmesi açısından önemli bir diyalogdur:

\begin{abstract}
"Ya, sonra İstanbul'un manevi yoksulluğu, cehaleti, hodgamlığı! Bütün bunları, bu tedavi isteyen sefaletleri bırakıp nereye gideceksiniz? Siz, başta olmadıkça biz, hiçbirimiz bu derin zulmetlerin içine girip onları aydınlatacak kuvvette değiliz. Bunu siz de biliyorsunuz. Halbuki Şark Türklerine bizim yol gösterdiğimizi söylüyordunuz. O halde?

Evet, Hazin Hanım, Türklerin birliğini doğuracak milletin uyanışı burada, Türkiye'de başlayacak, doğru! Bunun için de İstanbul'un fikir sefaletini, Anadolu'nun duygu sefaletini tedavi etmek lazım... Gayet doğru! Lakin bu mesele zannettiğiniz gibi yalnız bir cehalet, bir maarif meselesi değil, Hazin Hanım. (...) Fakirlik fakirlik! Anadolu'nun öldürücü hastalığı budur ve buna çare bulmak da maalesef, sizin, benim elimizde değil Hazin Hanım. Bu hükümetin vazifesidir” (Tek, 2002: 14-15).
\end{abstract}

Demir ile Hazin arasında geçen bu konuşmada hem Demir'in toplumda ekonomik bilinç kazandırılması hususundaki görüşlerine ve Hazin’in siyasi ve toplumsal olaylar karşısındaki sorumluluğuna yer verilir. Romanın olay örgüsündeki bu kısımlar kadınların hukuki, politik ve sosyal hayatın içinde erkeklerle eşit hâle gelmeye başladıklarını göstermektedir. Romanda Hazin’in kız kardeşi Nevin’in de yer yer erkeklerle toplumsal meseleler üzerine konuştuğu ve sosyal hayatın içinde aktif roller üstlendiği görülmektedir:

"Nevin, bu defa oldukça ciddi bir tavırla sordu:

-Peki ama Demir Bey, yalnız altmış milyonluk bir milletin saadeti ile uğraşmaktansa, bütün insaniyetin yükselmesine çalışmak doğru olmaz mı? (...) Hakkınız var Nevin Hanım, dedi. Bir milletin yerine bütün insaniyeti düşünmek daha büyük bir hakikattir” (Tek, 2002: 18-19).

Örneğin Demir ile Nevin arasında geçen bu konuşmada Nevin’in de tıpkı ablası gibi erkeklerle oturup aynı ortamda sohbet etmesi, Nevin'in de pek çok konuda fikir sahibi donanımlı bir kadın karakter olduğunu göstermektedir. Aslında romandaki bu gibi sohbetlerden feminizmin de hız kazandığı Meşrutiyet yıllarında toplumsal cinsiyet eşitsizliğine yönelik anlayışın yavaş yavaş değişmeye başladığı kanısına ulaşılabilir.

Demir ve Hazin'in milli mefkûre üzerine yaptıkları sohbetlerden anlaşılacağı üzere Demir, Semerkand'a giderken geçtiği her yerde Türk Ocağı kurmak ister ve her anlamda güvendiği Hazin’i de İstanbul'daki teşkilatta görevlendirmeyi arzular: "Hazin Hanım, sizi İstanbul Ocağı'nın azası, temeli yapıyorum, dedi. Sonra tebessüm ederek ilave etti. İlk öğrencim siz olacaksınız” (Tek, 2002: 41). Bu cümleden de anlaşılacağı üzere romandaki ideal erkek karakter Demir âdeta Hazin’i bu ulu davanın zaferle sonuçlandırılmasından sorumlu tutar ve onu bu davadaki ilk öğrencisi olarak kabul eder. Hatta Demir, Hazin'e o kadar çok güvenmektedir ki onun kaygılarını ortadan kaldırarak her yönden ona güç verip onu cesaretlendirir:

"Biliyorum, kirlenmiş ve eskimiş Bizans'ta milliyet tohumu kolay yetişmeyecek. İstanbul'a o kadar milletler temellük etmişler ki İstanbullu olup da bir milletin evlâdı olmak kabil olmuyor. İşte sizi 
ona bekçi bırakıyorum. İstanbul'u uyandırınız. Anadolu meselesini ortaya koyunuz ve Türkleri seviniz.

- Fakat ben bunları yapabilir miyim?

Demir'in sesi dargın yükseldi:

- Hazin Hanım, eğer milleti benim sevdiğim gibi sevseydiniz, yaparım diye cevap verirdiniz ve ona hizmet arzusuyla kuvvetinizin yüz misli olduğunu duyardınız" (Tek, 2002: 41).

Görüldüğü üzere Hazin'in her anlamda millet sevgisiyle dolu olduğunu bilen Demir, onun donanımının bilincindedir ve bu zor işin üstesinden gelebileceğine inanmaktadır: "Siz Türklüğü seviyorsunuz, biliyorum; fakat ben istiyorum ki siz yalnız onun hayatıyla yaşayınız. Bütün ömrünüzde onun istikbalinden maada (başka) emeliniz, aşkınız, sevgiliniz, ihtiyacınız olmasın! (...) ikisi de sustular. Düşünüyordular. Birlikte çalışa bilseydiler” (Tek, 2002: 41). Şevket Süreyya Aydemir'in de ifade ettiği gibi Demir "Dünyada son dileği, sevdiği Hazin'di. Yalnız onu sevdiği için değil, kendi yaydığı mefkûresini yalnız onun yaşatabildiği için, kendi ruhundaki kudrete yalnız onun aşkını denk bulduğu için Hazin’i arıyordu" (Aydemir, 2002: 158). Demir’in bu ifadeleri aynı zamanda Hazin'in romandaki fonksiyonunu ve siyasi görüşlerini de ortaya koymaktadır. Hazin ise bu güven ve övgüye layık olacak işler yapmaktadır. Örneğin Hazin, Neyyir’in savaşta ve Demir’in Trablusgarp’ta olduğu süre zarfında topluma hizmet amaçlı mektep açar:

"Bundan sonra hayatı daha acıklı devam etti, o, bu ruh durumuyla Demir'in telkin ettiği çalışma hayatına hazırlanacaktı.

Uzun bir beyin yorgunluğundan sonra duyulan maddi faaliyet arzusuyla, kendisini ezen bu elim rehavetten kurtulmak, bu rüyalar ve azaplarla dolu uyuşukluğu silkmek istedi; Türklük üstüne muhasebeler yaptı. Taraftarlar topladı. Cemiyetler yaptı. Gazeteler çıkardı. Türklük muhabbeti yaydı. Türklük cereyanı oldu. Türk müdafileri çıtı.!.. Lakin onun beyni yine dinlenemedi; yine üzülecek vakit buldu. Nihayet bir gün Demir'e söylediği mektebi hatırladı” (Tek, 2002: 57).

Hazin'in açtı̆̆ mektepte felsefe ve tarih dersleri verir. Platon, Nietzsche, Karl Marx'in fikirlerini topluma adapte ederek insanların üzüntülerini hafifletmeyi düşünür (Tek, 2002: 58). Hazin'in Demir'e olan özlemini unutmak için gününün büyük bir kısmını açtığı bu okulda ve Türk ocaklarına hizmet ederek geçirmesi ise aşkın yerini milliyetçi duyguya bıraktığının bir göstergesidir:

"O, idealistler yetiştirmeyi istiyordu. Buradan çlkarak talebe, doğrudan doğruya Demir'in talebesi olacaklardı. (...) Hazin ne kadar çalışmak lazımsa o kadar çalıştı; çünkü bu mektep Demir’e layık bir insaniyet aşkı mabedi olacaktı" (Tek, 2002: 58).

Aslında Neyyir de Hazin’in sevgisini kazanabilmek için vatanperver bir dava adamına dönüşerek cepheye gitme kararı alır (Tek, 2002: 55). Yani Neyyir’i cepheye götüren şey Hazin’in aşkını kazanabilmektir. Görüldüğü üzere romanda kahramanların birbirlerine duydukları aşk karakterlerin toplumsal bir ülkü edinmelerine neden olur: “Mektep!.. Demir’e veremediği hayatını, onun emeline veriyordu. Türk kızlarının nura can atan dimağlarına Demir'in ulvi ümitlerini yağdırırken duyduğu zevki, ihmal ki aşkı veremezdi” (Tek, 2002: 58).

Müfide Ferit Tek, gelecek nesillerin inşası için Osmanlı modernleşme süreciyle başlayan kadınların eğitiminin devamlılığına her zaman inanır:

“Eğitim konusunda ise kızlar, yine Tanzimat’tan önce, ancak Sıbyan mekteplerine gidebiliyorlardı. Burada, erkekler gibi sadece dinsel eğitim görebilmekteydiler. Yükseköğretimin görüldüğü medreselerde eğitim görmek imkânları ise bulunmamaktaydı” (Yılmaz, 2010: 198) 
Hazin’in kurmak istediği mektebin doğuş sebebi ise yazarın bu hususla ilgili düşünceleriyle benzerlik göstermektedir: "Bizdeki mekteplerin hemen hepsinin hedefi kız öğretmenler yetiştirmekti. Halbuki cemiyetin, yalnız kız öğretmen suretindeki mürebbiyeye değil, her terakki sahasında, her günkü yaşayışında, kadın irşadına ihtiyacı vardı” (Tek, 2002: 58).

Öte yandan Neyyir'in “Abla ne çalacaksın! Ya düşüneceksin, ya okuyacaksın, ya çalacaksın! Biraz da benimle konuşsan olmaz mı?...” şeklindeki sitemkâr bu sözlerinden anlaşlacağı üzere kadınların hayatın içerisinde sanat icra etmek, okumak, düşünmek gibi çeşitli görevleri olduğuna işaret edilmektedir (Tek, 2002: 22). Belli bir eğitimden geçirilmeyen kadınların kendi haklarından faydalanmaları biraz zor olacaktır. Müfide Ferit Tek de Feminizm başlıklı yazısında benzer görüsslere yer verir. Müfide Ferit'e göre "Sıcak, temiz medeni ve ahlâki bir aile ocağı” meydana getirebilmek için kadınların erkeklerle birlikte benzer haklara ve yaşam şekillerine sahip olmaları gereklidir. (Tek, 1335/1917: 307).

Yazarın tasavvur ettiğine göre Tanzimat'la başlayan değiş̧ime paralel olarak kadınlar Milli Mücadele yllarında toplum içerisinde hem cinslerini aşan bir konumdadır. "Kadınların II. Meşrutiyet'ten itibaren oy hakkı için mücadele ettikleri görülür. Bu dönemde birçok konuda olduğu gibi siyasi mücadelelerinde de kadına yol gösterici dönemin dergi ve gazeteleri olur" (Yllmaz, 2016: 37). Millî Mücadele döneminde hız kazanan kadınların daha fazla özgürleşmeleri ülküsüyle Cumhuriyet döneminde ortaya çıkan 'yeni erkek' ve 'yeni kadın' imajının temelleri atılır (Yılmaz, 2016: 38). İşte Aydemir romanında da yeni bir erkek modeli olarak Demir'in şahsında ideal kadını temsil eden Hazin'e yüklenen yeni misyon anlatılır. Tıpkı Meşrutiyet aydınları gibi Hazin'de romanda Türk kadınına inanmakta ve onlara çeşitli misyonlar yüklemektedir:

\begin{abstract}
"Bilhassa sefaletlerinde, acılarında cemiyet, kadın sevgisi arıyor, yaralarını bağlayacak kadın eli istiyordu. Niçin Avrupa'da olan o fedakâr, o güzide kadınlar bizde bulunmasın! Orada onların ekserisi en yüksek tabakaya mensup hanımlar, aile reisleri oldukları hâlde binlerce hayır cemaatleriyle uğraşmaya vakit buluyorlar ve bütün sstırap çekenlere annelik ediyorlar. İşte bizde böyle insaniyet ve şefkat mümessili kadınlar, cemiyete hizmet etmeyi ihtiyaç hâlinde duyacak alicenap hanımlar lazımdı. Hazin, bu boşluğu doldurmayı düşündü” (Tek, 2002: 58).
\end{abstract}

Aslında Hazin toplumun öngördüğü düzene göre yetiştirilmiştir. Aile mesuliyetini bilerek ve ailesinin istediği tarzda bir hayat sürmüştür. Lâkin zamanla hayatın içinde aktif bir rol üstlenmeye başlayan Hazin’in bu değişimi toplumun Meşrutiyet döneminde kadına bakış açısının da nassl farklılaştığını göstermektedir. Demir’in ölmeden önce yazdığı son mektubu toplumda değişen kadın karakterine iyi bir örnektir: "Ah zavallı Türkler... Biliyorum sizi orada tutan vazifeleriniz var... Lakin öyle zannediyorum ki orda sizin yerinizi tutacaklar bulunabilecek; lakin burası bomboş. Bütün arkadaşlar harbe gittiler. Bu korkularla elemliyim, son dakikalarım azaplı... Sizi bekliyorum” (Tek, 2002: 106). Zaten gerçek hayatın içinde de değişim pek çok sahada hayat bulur: "Meşrutiyet dönemi kadın faaliyetleri açısından oldukça renkli bir dönemdir" (Kurnaz, 2015: 155). İçinde yaşadığı kültüre ve normlara bağlı olan Hazin’in romandaki fonksiyonu daha çok toplumun kadına bakışının ve kadınlardan beklentilerinin farklı olması yönündedir.

Romanda Hazin şahsında örneklendirildiği gibi kadınlara her anlamda güvenilmeli ve hürmet gösterilmelidir. Hikâye boyunca kadınların kimliğine yapılan vurgu ise dramatik aksiyonu sağlayan aşk temasının arka planında anlatılmaya çalışılır. Bu tavır bir yandan ideolojik bir tipi oluşturmak bir yandan da okuru metne dahil etmekle doğrudan ilintilidir. Hazin'in aşkı milli duyguya dönüşünce yavaş yavaş aciz ve silik bir kahraman olmaktan uzaklaşır. Toplumun dışında kalan pasif kadın rolü ise ikinci planda kalır. Öyleyse bu roman insanın aklı ve iradesiyle hayatını şekillendirmesinin hikâyesi 
olarak okunabilir. Roman dış dünyanın kendilerine dayattığı davranış biçimlerini ortadan kaldırarak bireysel duygularıyla hareket eden kadınların pasif bir varlıktan uzaklaşmalarının anlatısıdır biraz da. Romanda mekân ve zamanın değişimiyle ortaya çlkan yeni atmosferin etkisiyle fonksiyonel olarak birey artık kendini "bireyleşim sürecinde" psişik anlamda var etmeye başlar.

Romanda milli kimlik arayışında halkı uyanışa sevk etme ve bilinçlendirme rolü ise idealize edilen bir kadın tipi olarak Hazin'e verilir:

"Türkleri uyandırmak. Lakin her şehirde, her geçtiğim yerde bir ocak kurmak istiyorum. Orada toplanacaklar ben gittikten sonra da benim başladığım işi devam ettirebilirler. Ve bu ocaklar teşekkül ettikçe birbirlerine de bağlı olacaklar. Ve bir gün gelecek, bunlar bütün Türk ili üstüne kurulmuş bir milliyet ağı gibi her tarafın birden tekâmülünü doğuracak” (Tek, 2002: 40).

Demir Anadolu dışında bu bilincin oluşturulması için çabalarken İstanbul'daki arkadaşlarının da aynı rolü üstlenmelerini onlardan ister:

\begin{abstract}
“Kirlenmiș ve eskimiș Bizans'ta milliyet tohumu kolay yetişmeyecek. İstanbul'a o kadar milletler temellûk etmişler ki İstanbullu olup da bir milletin evlâdı olmak kabil olmuyor. İşte sizi ona bekçi bırakıyorum. İstanbul'u uyandırınız. Anadolu meselesini ortaya koyunuz ve Türkleri seviniz” (Tek, 2002: 41).
\end{abstract}

Demir’in Millî Mücadele sürecinde yaşadı̆̆ 1 pek çok sorun olmuştur. Bunlardan biri de milli duygularla beşeri aşkı arasında sıkışıp kalmasıdır: "Yenmek lazım! Hayat nedir ki aşk ne olsun? Rüya, gölge! Halbuki beni çalıştıran emel bütün bir istikbal, bütün bir ebediyet temeli! Asırlara saadet hazırlayacak ilahi bir şefkat” (Tek, 2002: 76).

Demir her türlü zorluğa rağmen milli kimlik oluşturma sürecinde başarıya ulaşacağı zaman talihsiz bir olay neticesinde idam edilir. Hazin ise Demir'in ölümünü "-Senin sevgili ve mukaddes mezarın üstüne yemin ederim ki Demir, seni öldürmekle fikrini, emelini, mevcudiyetini öldüremezler...” şeklinde yorumlar (Tek, 2002: 129). Özellikle de savaş günlerinde yalnız kalan ve hayata tutunmaya çalışan, kadınlar için hayatta kalma ve toplumsal yaşam içindeki rollerini değiştirme bir zorunluluk haline gelir: "Yuvalar yıkı, yanan köylerin, şehirlerin alevleri semayı kızartıyordu. Kuru tarlaların sapanlarını, ölmüş öküzlerin yerine kadınlar çekiyordu” (Tek, 2002: 49).

Romanda memleket aşkıyla yanıp tutuşan Demir'in hayat hikâyesi anlatılırken Demir’in sevdiği kadına duyduğu özlem, güven ve ondan beklentileri de yan tema olarak karşımıza çıkar. Ölüm döşeğindeki Demir Hazin’e yazdığı mektupta ona beslediği aşkı ve yüklediği misyonu şöyle anlatır:

\footnotetext{
"Söyleyiniz Hazin Hanım, benim yerime gelmek istemez misiniz? Benim yerime, kardeşlerinizin yanına, onlara anneliğe gelmez misiniz?

Hayatımın büyük emelini ancak size emanet ederek ölmek istiyorum, bu emel benim hayatımın sebebi ve gayesi, mevcudiyetimin, mensubiyetimin hâkimi ve amili idi. Onu sizden başka kimseye emanet edemem..." (Tek, 2002: 105).
}

Dünya Türklüğünü uyandırmak ve ayağa kaldırmak şeklindeki idealini arkadaşlarıyla paylaşan Demir’i anlayan ve ona destek olan tek kişi Hazin'dir. Hazin’in bu cesareti ve ilgisi Demir'in gözünde onu yüceltmiş ve Hazin’e böyle bir mektup yazma ihtiyacı hisseder.

Milli mücadele metinlerinin pek çoğunda karşımıza çıkan "cephe gerisinin kahramanlarıdır aslında kadınlar” şeklindeki ifadeler Aydemir’in kadın karakteri Hazin içinde söylenebilir: 
"1908 sonrasında ise savaşlar kadın sorununa yeni boyutlar eklemiştir. Balkan ve Trablusgarp savaşları ile başlayan süreç toplumda ve ailede derin yaralar açmış, cephe gerisinde kalan kadın, toplumsal hayata ve ekonomik faaliyete katılmak zorunda kalmış” (Demircioğlu, 1998 (b): 14).

Milliyetçi ve vatansever kadınların yetiştirilmesine önem verildiği bu dönemlerde roman kahramanı Hazin'e de bu fonksiyonlar yüklenir. Kadına olan bakış açısının değiştirilmeye başlandığı yıllarda yazarın Türk kadınını merkeze alan romanlarının incelenmesi özellikle de milliyetçi feminist düşüncenin onun metinlerinden yola çıkarak tespit edilmesi açısından önemlidir.

Romanın sonunda Demir her ne kadar hayatını kaybetse de mutlu sona ulaşılır. Hazin için yeni bir hayat başlar. İdealleştirilmiş roman kahramanı Hazin’in artık hayattaki tek gayesi sevdiği adamın ona emanet ettiği ülküyü korumaktır. Geçen zaman içinde Hazin artık sadece Aydemir’in âşık olduğu kadın değil aynı zamanda yazarın vatanseverlik duygusunu öne çıkardı̆̆ı idealleştirilmiş kadın kahramanıdır. Yazarın ona yüklediği güçlü irade, azim, bilgi birikimi, zekâ gibi meziyetler ise aslında sosyal hayatta kadınların çeşitli haklara kavuşmaları gerekliliğiyle doğrudan ilişkilidir. Romanda sıradan bir tipin aksine ideal kadının temsilcisi olan Hazin’in aktif bir hayatının olduğu dikkatle anlatılmaktadır. Öte yandan hikâyede kadınların sosyal hayattaki farklı rollerine de dikkat çekilmektedir. Hazin prototipi, toplum içinde kadınların konumunun, değişiminin bir yansımasıdır aslında. Çünkü o tam bir teslimiyetle toplumsal normlar içinde yaşarken bir anda Millî Mücadelenin temsilcisi pozisyonuna geçer ve hayatı değişir.

\section{Sonuç}

Osmanlı aydını modernleşme sürecinde kadına ayrı bir önem vererek hem evde hem de sosyal hayatta çeşitli fonksiyonlar yüklemiştir. Özellikle de Tanzimat döneminde başlayan ve II. Meşrutiyet sürecinde hız kazanan vatanseverlik ve milli duyguların yüceltilmesi hususunda kadınların aktif bir rol üstlendikleri görülmektedir. Yani yeni toplumun inşasında kadının ayrı bir yeri ve önemi olduğunu düşünen Osmanlı aydını yeni bir kadın imajı oluşturmuştur: "Türk tarihinde kadın hareketleri için Tanzimat dönemi bir başlangıç oluşturmakla birlikte özellikle II. Meşrutiyet dönemi kadın vurgusunun yoğunlaştığı ve kadın kelimesinin altının özenle ve heyecanla çizildiği bir zaman dilimi olur" (Şermet, 2019: 141).

Meşrutiyet döneminde kaleme alınan eserler arasında yer alan Aydemir'de kendi de siyasi mücadelenin içinde yer alan Müfide Ferit Tek, kadın ve kadınlığa dair sorulara ve sorunlara yer vermiştir. Yazar özellikle de batılılaşma ve Millı̂ Mücadele'nin kazanılmasında kadınların toplumun her alanında aktif bir rol üstlenmesi gerektiğine inanmaktadır. Bu bağlamda Aydemir, Millî mücadele sürecinde sosyal hayatın içinde kadınların değişen rolü bağlamında ilgi çekici bir romandır. Özellikle İmparatorluktan ulus devlete geçişte kadınların toplum içindeki fonksiyonunun nasıl değiştiği hususuna yer verilen Aydemir, Osmanlı toplumunda kadının aile ve sosyal hayattaki değişen konumu ve kadın kimliğine yapılan vurgu açısından önem taşımaktadır.

Romandaki kadın karakterlerin fonksiyonundan anlaşılacă̆ı üzere artık kadınların da -erkek kılığına girmeden- savaş meydanlarında, siyasi mecralarda boy gösterdiği, eğitim hakkına sahip olduğu farkındalıklı dönemlere gelinir. Özellikle Anadolu'da yaşanan değişimin ardından Hazin’in değişimini normal karşlamamız gerektiğine dikkat çekilmektedir.

Ayrıca romanın kurgusunda beşerî aşkın milli aşka nasıl dönüştüğü anlatılmaktadır. Anlatıda cemiyetlerin ayakta kalabilmesi için kadınların da üzerlerine düşen vazifeleri faydalı bir şekilde yerine 
getirmeleri gerekliliğine dikkat çekilir. Milliyetçilik temasının işlendiği hikâyenin baş kahramanı Demir, ezilen Türk halkının çektiği sıkıntıları ortaya koymak için milli kimlik arayışındaki insanımızın yaşadığı sorunları Rusya'da yaşananları gözler önüne sererek anlatmaktadır. Demir toplumun çektiği tüm eziyetlere karşı halkımızı bilinçlendirmeyi amaçlar. Genç adam çıktığı bu yolda çeşitli zorluklarla karşılaşsa da ideallerinden vaz geçmez. Osmanlı’nın toplumsal yapısının gözler önüne serildiği ve aynı zamanda irdelendiği romanda yazarın halkçı söylemi, insanların mutluluğu misyonuna uygun bir tavırdır. Millî Mücadele'de Türk kadınının misyonunu ve fonksiyonunu tanıtan yazar, vazifesi ve aşkı arasında ulvi bir çaba göstermek zorunda kalan Demir ve Hazin’in yaşadıklarını anlatır. Bu aşk ise romanda Millî Mücadele süreciyle ilişkilendirilir.

Neticede Tanzimat'la başlayan hızlı batılılaşma ve trajik bir hâl alan medeniyet çatışması II. Meşrutiyet'in ardından da devam eder. Milli kimlik ve batılı hayat çatışması ise Aydemir romanının yan temalarıdır. Romanda Hazin Hanım'dan Avrupa'ya eğitim almak için gönderilen ilk kadın olarak bahsedilmektedir. Hazin Hanım ülkeye döndükten sonra meydanlarda halkı bilinçlendiren bir kadın kahramana dönüşür. Anlatıda Hazin Hanım’ın şahsında 19. yüzyılın ikinci yarısında kadınların toplumsal hayattaki rolleriyle ilgili bilgiye sahip olunmaktadır. Bu sebeple Aydemir romanı hem çağında hem de sonraki süreçte özellikle de kadınların sosyal hayat içindeki fonksiyonlarını anlattığı için kadın hakları hususunda önemli bir konuya sahiptir.

\section{Kaynakça}

Akman, F. (2020). "Müfide Ferit Tek ve Aydemir Romanına Dair Kısa Bir Mütalâa", http://mahzunbirokuyucu.blogspot.com/2014/05/mufide-ferit-tek-ve-aydemir-romanina.html (ET: 15.05 .2020$)$

Avcı, M. (2016). "Osmanlı Devleti’nde Kadın Hakları ve Kadın Haklarının Gelişimi İçin Mücadele Eden Öncü Kadınlar”, Atatürk Üniversitesi Türkiyat Araştırmaları Enstitüsü Dergisi, S. 55, ss. 225254.

Aydemir, Ş. S. (2003). “Aydemir”, Aydemir, ‘Ekler', İstanbul: Kaknüs Yayınları, ss. 155-159.

Belge, M. (2013). “Müfide Ferit Tek'in Aydemir Romanı”, Kitaplk, S. 63, ss. 89-96.

Demircioğlu, C. (1998b). "Müfide Ferit Tek ve Romanlarındaki Milliyetçilik”, Boğaziçi Üniversitesi Sosyal Bilimler Enstitüsü (Yayımlanmamış Yüksek Lisan Tezi), İstanbul.

Demircioğlu, C. (1998a). “İmparatorluktan Cumhuriyet'e Aydemir Müellifi Müfide Ferit Hanım”, Toplumsal Tarih, ss. 14-21.

Ertop, K. (2004). “Suyu Arayan Şevket Süreyya Aydemir”, Bütün Dünya, ss. 41-44.

Kaplan, R. (2002). “Aydemir”, Aydemir, ‘Ekler', İstanbul: Kaknüs Yayınları, ss. 163-168.

Kolcu, A. İ. (2018). Millî Edebiyat 2, Nesir / II. Meşrutiyet Sonrası Türk Edebiyatı, 9. bs., Erzurum: Salkımsöğüt Yayınları.

Köprülüzade, M. F. (2002). “Aydemir”, Aydemir, ‘Ekler', Kaknüs Yayınları, İstanbul, ss. 144-150.

Kurnaz, Ş. (2015). Yenileşme Sürecinde Türk Kadını (1839-1923), İstanbul: Ötüken Neşriyat.

Mansuroğlu, M. (1972). “Özgürlük Savaşında Türk Kadını”, Türk Soroptimisti In Memoriam Müfide Ferit Tek (Özel Sayı), İstanbul: Çeltüt Matbaası, ss. 40-43.

Seyfettin, Ö. (2002). “İnkılâplarda Kadın”, Aydemir, İstanbul: ‘Ekler’, Kaknüs Yayınları, ss. 151-154.

Soğukömeroğulları, M. (2020). "Müfide Ferit Tek”, Türk Edebiyatı İsimler Sözlüğü. http://teis.yesevi.edu.tr/madde-detay/tek-mufide-ferit (ET: 20.05.2020).

Sünbüloğlu, N. Y. (2012). "Ulusun Umudu ve Felaketi Erkekler: Milliyetçi Kadın Yazarların Romanlarında Erkeklik Kurguları (1918-1951)”, Türk Sağı: Mitler, Fetişler, Düşman İmgeleri, 
(der. İnci Özkan Kerestecioğlu ve Güven Gürkan Öztan), İstanbul: İletişim Yayınları, ss. 509537.

Şermet, K., S. (2019). "Müfide Ferit'e Özgü Feminizm”, Karabük Üniversitesi Sosyal Bilimler Enstitüsü Dergisi, 9 (1), ss. 140-159.

Tek, M. F. (1335/1917). "Feminizm 1", Türk Kadını, C. 1, S. 20, ss. 305-308.

Tek, M. F. (1335/1917). "Feminizm 2", Türk Kadını, C. 1, S. 21, ss. 323-326.

Tek, M.. F. (1972). "Hayat Hikâyem”, Türk Soroptimisti In Memoriam Müfide Ferit Tek (Özel Sayı), İstanbul: Çeltüt Matbaası, s.48.

Tek, M. F. (2002). Aydemir, İstanbul: Kaknüs Yayınları.

Üngör, B. Z. (1972). “I. Ölüm Yıldönümünden”, Türk Soroptimisti in Memoriam Müfide Ferit Tek (Özel Sayı), İstanbul: Çeltüt Matbaası, ss. 40-41.

Yardım, M. N. (2008). "Müfide Ferit Tek ve Hatırlattıkları", Ufuk Ötesi, http://www.ufukotesi.com/yazigoster.asp?yazi_no=20030451 (ET: 24.05.2020)

Yılmaz, A. (2010), “Osmanlı'dan Cumhuriyet'e: Kadın Kimliğinin Biçimlendirilmesi”, Çağdaş Türkiye Tarihi Araștırmaları Dergisi, S. 20-21, ss. 191-212.

Yılmaz, T. (2016). “1923-1940 Arası Cumhuriyet Dönemi Kadın Romanlarında İdeal Kadın Tipi Olarak Erkekleşen Kadın”, Rumelide Dil ve Edebiyat Araştırmaları Dergisi, S. 7, ss. 35-51.

Zengin, M. (2017). "Agglutination of the Turkish Ideal and Western Literature, Religion and Mythology in Müfide Ferit Tek's Aydemir”, Turkish Studies, Volume 12/5, ss. 559-578. 